\title{
The Plight of Refugee Claimants
}

\author{
David Matas \\ to The Amnesty International Group 19 \\ Winnipeg, November 15, 1984
}

Refugee claimants are among the most wretched people in Canada. They have fled countries where they have been imprisoned for their beliefs, they may have been tortured, their lives may have been threatened. They know no one or almost no one in Canada. They normally cannot speak either French or English. A refugee claim can take years to process before a final determination is reached. Until a person is recognized as a refugee, he is not recognized as a resident, even thought he may be here for years. Despite his lengthy stay, he is treated as if he will be leaving in a week or two.

There are few areas of life that are not regulated by government and there are few areas of government regulation where residency does not make a difference. Whenever residency does make a difference, a refugee claimant suffers. On top of it all, there is a conscious effort not to make refugee claimants too comfortable here, for fear it will lead to abuse of the refugee claims system. Refugee claimants, by and large, come from

Third World countries, that lack the standard of living and infrastructure of Canada. Allowing refugee claimants too easy access to a Canadian standard of living would, it is feared, attract frivolous refugee claimants trying to benefit from a temporary stay in Canada. The result is that the misery refugee claimants suffer is not just circumstance. It is there by design.

Complicating the problems the claimants face is the fact that there are two ways of making a refugee claim, in status and out of status. The problems a claimant faces depends on whether he makes his claim in status or out of status.

An in status claim is a claim made while the claimant is still a visitor in Canada. If a person makes a claim in status, his status is extended until the claim is determined. The person, theoretically, retains his status as a visitor.

An out of status claimant is a person who has lost his visitor's status, or who never had visitor status. Such a person has no status in Canada. $\mathrm{He}$ is in Canada pending determination of his claim, and for no other reason.

The problems refugee claimants face can be seen in the work permit system, in their work search efforts, in the school permit system, in medicare, in legal aid, in welfare, in family allowance, in drivers' licences and the difficulties they face in family reunion.

\section{Work Permits}

One general rule is that a foreign worker has to apply from outside Canada to get a work permit. Another general rule is that the claimant must have a job offer certified by the Government of Canada as being a job for which no Canadian is available.

Out of status refugee claimants are exempt from both of the rules. An out of status refugee claimant may obtain a work permit, even though he applies from within Canada. He may obtain a work permit even though the Government of Canada is not prepared to certify that there is no Canadian available for the job. Superficially, refugee claimants are advantaged by these exemptions. However, these exemptions are the cause of a lot of their problems. There is a suspicion that refugee claimants come to Canada, not to seek protection, but in order to benefit from these exemptions. This suspicion works against claimants in a number of ways. It makes their refugee claims harder to establish. A refugee claim invariably depends on the credibility of the claimant. When a claimant benefits financially from making a claim, his credibility is put under cloud. The suspicion creates a countervailing tendency. There is a tendency to prevent claimants from doing too well financially.

A work permit will be given only if the claimant will be destitute without it. If he has friends or relatives in Canada willing to support him, he will be denied a work permit. To obtain a work permit, he must establish, to the satisfaction of immigration officials, that his friends and relatives in Canada are not willing or able to support him. If one member of the family is working, then other members of the family cannot work. An exception is made only where the family would be eligible for welfare, even with one family member working. In that case, a second family member will be allowed to work. If a claimant has a work permit for one job, he will not be given a work permit for another. He will not be able to hold two jobs at once. Again an exception is made only where the claimant, without the second job, would be eligible for welfare. The effect of these restrictions is to impoverish claimants. They are allowed to earn enough to keep off welfare, but no more. Government thwarts any earning initiative beyond that.

For in status claimants, the situation is even worse. An out of status claimant may not be entitled to a work permit, but at least he is eligible to be considered for one. The immigration manual the government puts out as guidelines for immigration officers says that in status claimants do not enjoy any privilege provided under the Immigration Act to an out of status claimant in respect of eligibility for employment authorization. The department has the power to refuse even to consider an application for a work permit made by a refugee claimant in status. 


\section{Work Search}

Through the Canada Employment and Immigration Commission (CEIC), the Government of Canada offers an employment service, matching job offers with job applicants. It is a heavily used service, particularly for unskilled labour.

Refugee claimants cannot take advantage of this service. They are not allowed to register with CEIC. The government restricts the service to residents of Canada. Refugee claimants must find work on their own.

\section{Schooling}

In status claimants have to conform to the terms in which status was granted in order to retain their status. They can go to school only if they have permission to go to school, given by the Department of Immigration.

The department will give permission to go to school only to minor dependants of refugee claimants. It will not give permission to go to school to adult refugee claimants. The position of the department is that "studies are not considered necessary for subsistence while a claim is being determined." Before a minor dependant is given permission to go to school, there must be a statement from the school that any non-resident fees that are payable have been paid. Schools do not have to charge refugee claimants non-resident fees. If they do, the charges can be onerous.

Out of status claimants can go to school without authorization. There is no blanket permission in the law. There is just no provision in the law for out of status refugee claimants who wish to go to school. Because the law does not provide for the situation, immigration officials have no say in whether out of status refugee claimants go to school or not.

CEIC finances training programs at community colleges, and on-the-job training to give Canadians the skills they need to find work. Refugee claimants are ineligible for these training programs. Because they are not permanent residents, they need - not apply.

4. Medicare

Medicare eligibility is determined provincially, not federally and eligibility can vary from province to province. In Manitoba, according to the Manitoba Health Services Commission, a refugee claimant is eligible for medicare once he has work permits totalling twelve months or more. A claimant need not have one work permit totalling twelve months or more. It is enough if he has several work permits that together total twelve months or more. A claimant need not have actually worked twelve months. His eligibility commences as soon as he receives a work permit that will take him to twelve months. So, for instance, if he is given a sequence of four three-month work permits, then, after nine months, after he received his fourth permit, he would be eligible for medicare. This rule imposes a deprivation on refugee claimants. Claimants do not get work as soon as they arrive in Canada. They may not get work at all.

Private health insurance may simply not be available. Manitoba Blue Cross has a visitor health care plan. The application must be received by Blue Cross within seven days of arrival in Manitoba. The terms of the policy plus all extensions cannot exceed 32 days. Persons applying for immigrant status are not eligible for coverage under the plan.

A person denied medicare is not denied medical help. Doctors and hospitals will give medical help to refugee claimants, but they will charge the claimants. These charges can discourage people from seeking medical care they need. If the charges are not paid, they may be put out to collection. Harassment by bill collectors is an additional trouble refugee claimants hardly need.

\section{Legal Aid}

Like medicare, legal aid is a provincial matter. Legal aid eligibility rules can vary from province to province. In Ontario, the regulations provide that each area director has the power to issue legal aid certificates to residents. Area directors cannot issue legal aid certificates to non-residents. Only the director of legal aid can do that. In practice, in Ontario, except in a rare case, refugee claimants are not issued legal aid certificates.
The Canadian refugee determination process is complex. A claimant without a lawyer can be at a serious disadvantage. There are lawyers who will volunteer their services when legal aid is not available. The unavailability of legal aid can discourage a claimant from even approaching a lawyer to act.

\section{Welfare}

Welfare is, theoretically, subject to national standards. The Canada Assistance Plan provides for federal cost sharing of provincial welfare. Under the plan, need is the only criterion for welfare eligibility. Residence in Canada is not relevant.

There have been, in spite of federal requirements, provincial restrictions based on residency. The B.C. welfare regulations provide that a welfare recipient must be either a Canadian citizen or a permanent resident. In one case, the B.C. welfare authorities gave welfare to a refugee claimant. The B.C. government appealed the granting of welfare to the courts. The Supreme Court of B.C. held that the B.C. welfare regulations prohibited a refugee claimant from getting welfare, since such a person was not a resident.

It is cold comfort to refugee claimants that British Columbia is in violation of the Canada Assistance Plan. The Minister of Employment and Immigration has sided with refugee claimants and against the Government of B.C. on this issue. Yet refugee claimants in B.C. are still ineligible for welfare.

\section{Family Allowance}

According to the Family Allowances Act, to be eligible for family allowance, a person must be a citizen, a permanent resident, a visitor, or the holder of a permit. According to the Family Allowances Regulations, if a person is eligible as a visitor or holder of a permit, he must be authorized to remain at least twelve months, and his income must be subject to income tax.

Out of status refugee claimants are neither visitors nor permit holders. They are, in principle, not eligible for family allowance.

In status refugee claimants are visitors. An in status refugee claimant 
Univer of Tor Lib/Serials Dep

TORONTO ON M5S 1 A5

would be eligible for family allowances, provided he was authorized to remain at least twelve months, and his income was subject to income tax.

However, in status claimants are not entitled to be considered for work permits. In status claimants are denied work permits, simply because they are in status. An in status claimant will normally be unable to earn the income and pay the income tax that will allow him to receive family allowance.

\section{Drivers' Licences}

Provincial Highway Traffic Acts typically provide that a non-resident may drive without a licence issued by the province for three months. A nonresident can rely on any licence he may have been issued by the jurisdiction from which he came.

The acts do not say that a person has to be a resident to obtain a driver's licence. In practice, that is how they are interpreted. Refugee claimants are denied the possibility of applying for drivers' licences. If they appeal to supervisory staff, the initial decision may be reversed. However, the initial refusal may be enough to discourage claimants from going any further.

\section{Family Reunion}

Adding to the hardships of grappling with government bureaucracies is the fact that refugee claimants are often alone. If they came from a country with a visa requirement, a visa will not be issued to allow their families to join them. The Government of Canada will not issue a visitor's visa to a spouse or children to allow them to join refugee claimants in Canada.

Only permanent residents and citizens can sponsor their immediate family to come to Canada. Refugee claimants, whether in status or out of status, will not be allowed to sponsor their families for entry into Canada.
Because a refugee claim can take years before it is finally determined, claimants can be separated from their families for a prolonged period of time. This prolonged separation can lead to marriage breakdown and disintegration of the family unit. Spouses abroad are unaware of the complexities and delays of the refugee system. They may believe that the claimant spouses are just refusing to send for them.

\section{Recommendations}

A Conference on Refugees and Settlement held recently in Winnipeg, sponsored by the Citizenship Council of Manitoba, the Anglican Church in Winnipeg, and the Interfaith Immigration Council, dealt with the plight of refugee claimants. A Workshop came up with a number of recommendations. Some of these were:

a) In status claimants be eligible for work permits.

b) Work permits not be denied because of permits held by spouses.

c) Work permits for additional jobs not be denied.

d) Work permits not be denied because a friend or relative is willing or able to assist.

e) Schools not charge non-resident fees to refugee claimants and their dependants.

f) In status claimants and their dependants be given permission to attend school.

g) Refugee claimants be covered by medicare from the date of their claim.

h) Legal aid be available for refugee claimants.

i) Refugee claimants not be denied welfare by virtue of their status or lack of status in Canada.

j) Refugee claimants be entitled to family allowance on making a claim.

\section{Conclusions}

Refugee claimants should not be discouraged from making refuge claims by making them miserables Canada. Enforced misery is not in appropriate abuse control mechan ism. It is a mechanism that, regret. ably, is being used not only or even most stringently in Canada. Scand navia, Switzerland, and West Ger. many have all fallen prone to the same technique.

In Switzerland, all refugee claimant are denied work permits. In West Germany, refugee claimants are put in camps. The United Nations High Commission for Refugees has reported "shocking and inhuman" conditions at these camps. The UN has said of Switzerland, Scandinavia, and West Germany that there is a negative attitude that attempts to raise in asylum seekers the desire to return to their own country and to dissuade potential new arrivals. Those governments believe that significant number of asylum seekens are fake refugees, people simply looking for a better way of life. The governments are determined not to make life better, to make it worse than the Third World conditions from which these claimants came."

This enforced misery makes no dis: tinction between the abusers and the genuine refugee. The genuine refugee suffers as much as someone who has come looking for a better way of life. The way to control abuse is a speedy determination of $\mathbf{a}$ refugee claim. A speedy determina tion will deny abusers a long stay in better conditions than exist at home. Would-be abusers will not incur the expenses of the trips if the stays the can engineer by abuse are invariably short. Real refugees in Canada must be treated in a humane fashion.

David Matas is a lawyer in private practice in Winnipeg. He chaired workshop on refugee claimants for the Conference on Refugees and Set tlement. 